\title{
マイクロカプセル化学塞栓療法における 末梢血細胞性免疫能
}

\author{
佐藤一成・阿部良悦・守山正胤・加藤哲郎*1), 海野勝男 ${ }^{* 2)}$
}

Cellular immunity of peripheral blood in arierial embolization with microencapsulated anticancer drugs

Cellular immune parameters in peripheral blood were monitored for 4 weeks after chemoembolization with microencapsulated anticancer drugs, in order to investigate possible immune consequences after the therapy.

The number and median age of the subjects were 30 and $63(48-79)$, respectively. The subjects all had urological malignancies including 7 renal cell carcinomas, 3 renal pelvic carcinomas, 13 bladder carcinomas and 7 prostatic carcinomas.

Natural killer(NK) cell activity and $\mathrm{CD} 4 / 8$ ratio were augmented in $60 \%$ and $77 \%$ of the cases after chemoembolization respectively. Mature NK cell population $\left(\mathrm{Leu}^{-} \mathrm{CD}^{-} 6^{+}\right.$) in these cases also showed a trend of contineous increase for more than 4 weeks. On the other hand, a small number of the patients showed an augmentation of $\mathrm{CD}^{+}$cells, I a$1^{+}$cells or response to phytohemmagulutinin.

These findings suggest that enhanced natural killer cell activity could be anticipated in more than a half of cases after chemoembolization.

Kazunari Sato $\cdot$ Ryoetsu Abe $\cdot$ Masatsugu Moriyama Tetsuro Kato*1), Katsuo Unno*21 key words : natural killer cell activity, chemoembolization, cellular immune parameter, microcapsule, targeted chemotherapy

筆者らは, ターゲティング化学療法の原型とし て, 抗癌剤マイクロカプセルを開発し, 各種悪性 腫瘍に術前補助療法として応用してきた ${ }^{11}$. そし て, 本法施行後に手術を行った stage $2 \sim 3$ の掔癌

*1) Department of Urology, Akita University School of Medicine 秋田大学医学部流尿器科学教室

*2) Department of Pharmacy, Akita University School Hospital 秋田大学医学部付属病院薬㓮部
ならびに膀胱癌では，本法を行わずに手術した対 照群に比較して, 予後の改善がみられることを報 告してきた ${ }^{2,3)}$.このような局所浸潤癌では, 微小 転移, 手術時腫崵細胞播腫の危険性があり, 最終 的にはこれら微小癌病巣の進展によって予後が規 定されることから，化学塞栓療法による手術成績 の向上は本療法に微小癌病巣を抑制するなんらか の作用があることを推察させる.

これを宿主防御機構の面からみるため, 化学塞 栓療法前後で NK 活性を中心とした末梢血中細 胞性免疫の変化を検討してみた。

\section{対象と方法}

対象は腎癌 7 例, 腎孟癌 3 例, 膀脂癌 13 例, 前 立腺癌 7 例の合計 30 例であった。年齢中央值は 63 歳 (48〜 79), 男性 23 例, 女性 7 例であり, 腫瘍 進行度はまちまちであったが, 全例 1 日の $50 \%$ 以 上起床可能で performans status 2 以下であっ た. 抗癌剤マイクロカプセルは, mitomycin C 18 例, cisplatin 5 例, peplomycin 1例, ならびに それら併用 6 例であり, 投与量中央值はマイトマ イシン C $20 \mathrm{mg}$, シスプラチン $100 \mathrm{mg}$, ペプロマ イシン $80 \mathrm{mg}$ であった(表 1 ).

化学塞栓療法前， 3 日後， 1 週， 2 週， 3 週， 4 週後に患者末梢血を採取し，K-562 細胞を標的 とした natural killer(NK) 活性ならびに phytohemagglutinin(PHA)刺激によるリンパ球幼若化 能を測定した. また, Ortho 社および Becton Dickinson 社モノクローナル抗体を用い, flow cytometric analysis を行った. 用いた抗体は CD 3 (pan-T cell), CD 4 (helper/inducer T cell), CD 8(supperessor/cytotoxic $\mathrm{T}$ cell), CD 16(NK cell), I a-1(HLA-DR)ならびに Leu 7(NK/K 
表 1 patient characteristics and microcapsule therapy

patient :

$$
\left\{\begin{array}{lc}
\text { No. Pts. } & 30 \\
\text { age } * \text { (Range) } & 63 \text { yrs. }(48 \sim 79) \\
\text { sex }(M: \text { F }) & 23: 7 \\
\text { PS, grade } & \text { I }-23, \text { II }-7
\end{array}\right.
$$

tumor :

$\left\{\begin{array}{lr}\text { renal cell Ca. } & 7 \\ \text { renal pelvic Ca. } & 3 \\ \text { urinary bladder } \mathrm{Ca} . & 13 \\ \text { prostatic } \mathrm{Ca} . & 7\end{array}\right.$

microcapsule
$\left\{\begin{array}{lr}\text { mitomycin C } & \text { dose }(\mathrm{mg}) \\ \text { cisplatin } & 100 \\ \text { peplomycin } & 80\end{array}\right.$

- median

cell)である.なお, 当観察期間には，他の治療は 行わなかった. また, 治療前後の免疫パラメーター の変動を実測值をもとに paired $\mathrm{t}$ test により検 定した.

\section{結 果}

末梢血 $\mathrm{NK}$ 活性を化学塞栓療法前値との比と してあらわすと, NK 活性の変動は患者ごとに大 きなばらつきがみられた(図 1 )。治療後 5 回の測 定のうち, 連続する 3 回以上の測定值が治療前值 を上廻るものと (図 1 中の実線), それ以外のもの (点線)に大別してみた. その結果, 前者は 30 例中 18 例, 後者は 12 例であり,これら 2 群の平均值の 変化を㭘討した. 便宜上, 前者をタイプA, 後者 をタイプ $\mathrm{B}$ をると, タイプ $\mathrm{A}$ は免疫活性の増強 を，タイプBは免疫活性の低下を示すと考えられ る. 以下, 他の免疫パラメータについても同様に 取り扱った. NK 活性はタイプA群では 3 日目に 一旦低值となるが, 1 週間後に 1.59 倍と有意に上 昇し $(\mathrm{P}<0.05)$, 以後徐々に低下したが，4 週間 後でもわずかに治療前值を上廻っていた(1.28 倍).これに対して, タイプB群では 3 日目に最低 值を示し，4週後でも治療前值に回復しなかった (図 2). また, 腫湟別の NK 活性の反応をみると, 腎細胞癌では 7 例中 3 例 $41 \%$ がタイプAである のに対し, 腎孟癌, 膀胱癌前立腺癌では半数以上 がタイプAを示していた，つぎに，抗腫瘍効果が

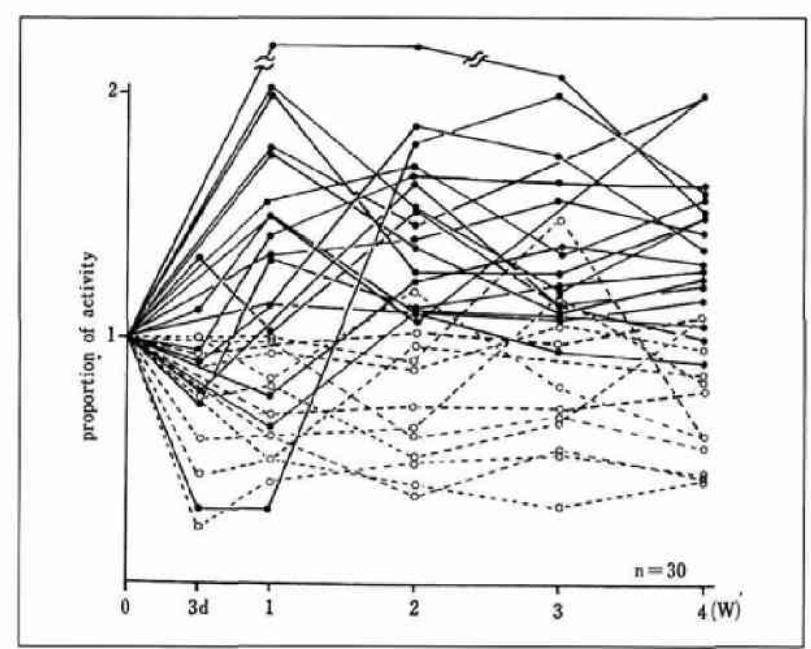

図 1 natural killer activity afer chemoembolization

Solid lines represent cases whose serial three postotreatment values of NK cell activity are higher than its pretreatment value, and dotted lines represent the remainings.

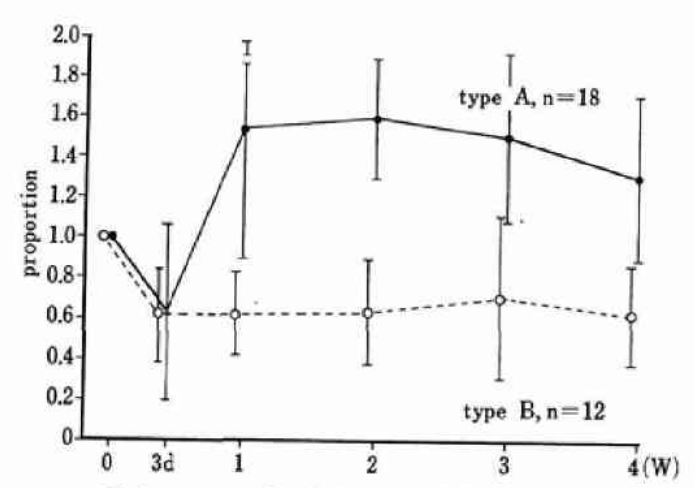

図 2 natural killer activity after chemoembolization

These curves show changes of mean propor. tions of NK activtiy between pre-and postotreatment. Vertical bars indicate standard deviation. Type A or B stand for NK activity augmented after chemoembolization or not, respectively.

判定できた 21 例について, NK 活性の変化との相 関をみた. NK 活性がタイプAを示したのは, MR 以上では 15 例中 8 例 $53 \%, \mathrm{MR}$ 末満では 6 例中 2 例 $33 \%$ であり，例数は少ないが抗腫瘍効果がみ られた群に NK 活性増強例が多い傾向がみられ た. 


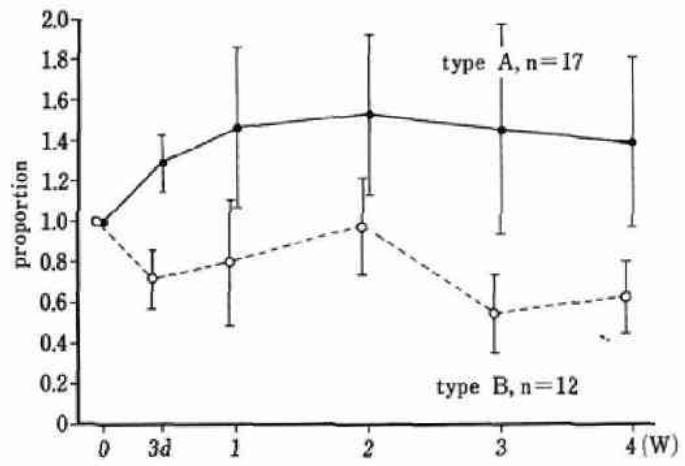

图 3 Leu7-CD16+ lymphocyte population

Type A or B stand for the population aug. mented after chemoembolization or not, respectively.

この間の $\mathrm{NK}$ サブセット (Leu 7- CD 16+) の変 動をみると, タイプA群は 29 例中 17 例 $59 \%$, 1 週から 4 週にかけて CD 16+ Leu 7- 陰性細胞が 持続的に増加する傾向がみられ, 成熟 NK 細胞比 率が増加していた。また，NK 活性がタイプAを

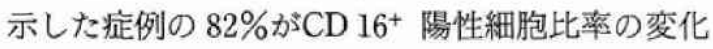
においてもタイプAを示した(図 3 ).

$\mathrm{CD} 4 / 8$ 比は治療後 22 例中 17 例 $77 \%$ で反応の 增強がみられた. タイプ A群では治療後早期に最 も高く,その後は徐々に低下するものが多かった。


$\mathrm{CD} 4 / 8$ 比も同じくタイプAを示した(図 4).

CD 3 陽性細胞比率では, 治療後のタイプA群と タイプB群の例数が同程度で, 経時的変動はほと んどみられなかった。 また，I a-1 陽性細胞には 治療前後で明らかな変化はみられなかった。

PHA 刺激下リンパ球幼若化反応の stimulation index (S. I.)がタイプA を示しものは 25 例中 10 例のみで，15 例がタイプBに分類された. タイ プAでは治療後リンパ球 S. I. が治療前の数倍に 六進するものがあり, 全体として大きな fluactuation を示したが 4 週でも高値を持続した.

\section{考 察}

本研究では, マイクロカプセル化学塞栓療法に よる各症例の免疫能の変化に注目するため, 免疫 パラメーターを治療前後の相対值で表示し, かつ 3 測定期間以上にわたって治療前值を上廻るもの を反応増強と判定した. その結果, T-cell 数と

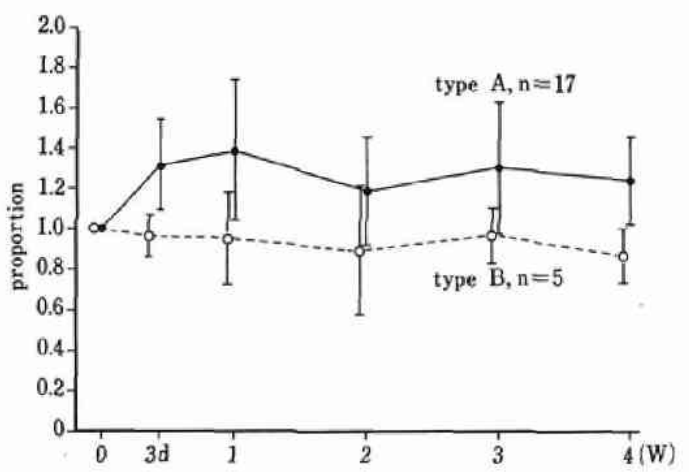

图 4 OKT4/8 ratio after chemoembolization Type A or B stand for the ratio augmented after chemoembolization or not, respectively.

PHA 刺激反応では器械的動脈塞栓療法における 諸家の報告 ${ }^{4 \sim 6)}$ と同样に, 明らかな活性の増強を認 めなかった。しかし, NK 活性は化学塞栓療法後 に $60 \%$ の例で増強し, かつ, それらの $\mathrm{NK}$ 活性平 均値は 4 週後でも治療直前に比較して, 高值を示 していた．また，この期間は $\mathrm{NK}$ 細胞サブセット のなかで, Leu 7- CD 16+ 細胞が, 59\%の症例で 持続的に増加する傾向がみられた， NK 細胞の分 化・成熟は, Leu $7^{-}$Leu $11^{-}\left(\right.$CD 16) $\rightarrow$ Leu $7^{+} 11^{+}$ $\rightarrow$ Leu $7^{-} 11^{+}$という過程をとるとされることか $ら^{7,8)}$, 化学塞栓療法後には NK 細胞の分化・成熟 が促進されることが示された。

化学塞栓療法後の NK 活性増強の機序を考え るうえで, Johnson \& Kalland ${ }^{9)}$ の実験が興味深 い. 彼らは, マウス腎に同種または異種腫瘍を移 植し，5 日後に腎動脈を結紮した結果，いずれの 腫瘍を持つマウスでも脾細胞の NK 活性が増強 することを認めた. 健常腎の腎動脈結紮では, NK 活性の増強がなかったことから，前者の免度賦活 機序を腫瘍梗塞によってリンパ組織や血液中に大 量の腫瘍抗原が放出された結果によると推察し た. ヒトでは動脈塞栓術後に特定の埂瘍抗原が放 出されるかどうかは不明であるが, 所属りンパ節 には種々の刺激反応がみられ，腫瘍間質には $\mathrm{M} \phi$ を主とした細胞浸潤が認められている ${ }^{9,10)}$.このよ うな部位では，M申を主体とした抗原提示細胞が 壊死单からの抗原を処理し, CD 4+ T-cell を介し た細胞性免疫の賦活へ進みうるものと推察でき る.この際, 活性化した $\mathrm{M} \phi$ と T-cell は, いく 
つかの cytokine を放出するが，NK 細胞はそれ らのうち IFN と IL-2 によって活性化されるこ とが知られている8,11).さらに, 腫瘄壊死組織加ら 直接 NK 活性を増強する可溶性物質が放出され る可能性も指摘されている10).

化学塞栓療法は, カプセルの塞栓と抗癌放徐放 作用を利用したターゲティング療法であり, 通常 の動注療法, 器械的塞栓あるいは両者の併用に比 較して抗腫瘍効果にすぐれている11. したがって, それだけ腫瑝抗原の放出も大きいと考えられ，上 述したような $\mathrm{NK}$ 活性增強がより起こりやすい 状況になっていると推察できる. NK 活性増強例 にMR 以上の反応が多かったこと, 化学塞栓療法 に対して抵抗性を示す腎癌 ${ }^{12)} に$ 比して膀胱癌，前 立腺癌に NK 活性増強例が多い傾向があったこ とは，ての間接的な裏付けと考えられる.

一般に，抗癌剤は免疫担当細胞を産生する骨咀 を抑制するが, 本療法では全身循環血中の抗癌剤 は低濃度に留まり，骨髄抑制は少ない22.このよう な特徵は $\mathrm{NK}$ 活性を含む免疫活性の增強に有利 と考えられる。 また, 抗癌剤が suppressor T-cell を抑制する場合をはじめとして，特定の条件下で は抗癌剂が免疫系に賦活効果を及ほしうることが 報告されている3,14). 本療法の後には, $\mathrm{CD} 4 / 8$ と NK 活性の增強を同時に示す例が多かったことか ら, 循環血中の低濃度抗癌剂が免疫活性の増強に 作用した可能性も否定できない.

NK 紐胞は, 初期癌や転移形成の過程に対して 抑制効果を持つと考えられている(1). NK 活性が 遠隔成績とよく相関する ${ }^{15)}$ という報告は，一つの 証拠とされる. 化学塞栓療法後にみられた NK 活 性の増強も, 同時に所属りンパ節や遠隔部の微小 転移巣になんらかの抑制効果を発揮している可能 性がある、また，筆者らは，NK 活性が高值に維 持される化学塞栓療法の $3 \sim 4$ 週間後に手術を施 行しているが,このことが手術時の腫瘍播種によ る転移形成を抑制することも推察される、このよ うな免疫学的機序が局所浸潤性腎癌と膀胱癌にみ られた術後再発の抑制と予後の改善 ${ }^{2,3)}$ に多少と も反映されているのではなかろうか.

\section{結 論}

マイクロカプセル化学塞栓療法後の免疫パラ
メー夕は，症例により大きな較差がみられた。し かし，過半数では NK 活性 (60\%)，CD 4/8(77\%) 比の増強がみられ，このような例では同時に成熟 型 NK 細胞比率が上昇する傾向がみられた， CD 3 または I a-1 陽性細胞比率と PHA 幼若化能で は増強パターンを示す例は多くなかった.

以上の結果, 抗癌剤マイクロカプセル化学塞栓 療法後には, 約半数の症例で NK 活性を中心とし た紐胞性免疫機構による補助的効果が期待できる ことを示唆する.

\section{文 献}

1) Kato, T. : Encapsulated drugs in targeted cancer therapy. Controlled drug delivery. vol.11. Clinical Application. CRC Press, Florida, 1983 p 189-240.

2）阿部良悦, 加藤哲郎, 森 久, 佐藤一成, 守山正指： 督癌に対するマイトマイシンCマイクロカブセル術前 補助療法. 日癌治誌 $20(3): 535-541,1985$.

3）佐藤一成, 加藤哲部, 守山正版, 阿部良悦, 土田正義： 膀胱癌に対するマイクロカプセル手術補助療法. 日泌 尿会誌 79(12)：2002-2011，1988.

4) Nakano, H., Nihira, H., Toge, T.: Treatment of renal cancer patients by transcatheter embolization and its effects on lymphocyte proliferative responses. J. Urol. $130: 24-27,1983$.

5) Carmignani, G., Belgrano, E., Puppo, P., Cornaglia, P. : T and B lymphocyte levels in renal cancer patients: influence of preoperative transcatheter embolization and radical nephrectomy. J. Urol. 118: 941-943, 1977.

6）大崎往夫, 清水達夫, 伊藤克彦, 滪口 拓: 肝紏胞癌 に対する動脈塞栓療法における免疫学的パラメー夕の 変動一NK, ADCC 活性を中心に一, 消化器と免疫 No. 14, 日本医学館, 1985, p 216-220.

7) Pizzolo, G., Semenzato, G., Chilossi, M., Morittu, L., Smbrosetti, A. et al. : Distribution and heterogeneity of cells detected by HNK-monoclonal antibody in blood and tissues in normal, reactive and neoplastic conditions. Clin. Exp. Immnunol. 57 : 195-206, 1984.

8）安保 微, 伊藤公志, 沢田秀明：NK 紐胞をめぐって 一最近の知見加ら。臨床免疫 19(5)：361-376, 1987.

9) Johnson, G., Kalland, T. : Enhancement of mouse natural killer cell activity after dearterialization of experimental renal tumors. J. Urol. $132: 1250-1253$, 1984.

10) Bakke, A., Gothlin, J. H., Haukaas, S. A., Kalland, $\mathrm{T}$. : Augmentation of natural killer cell activity after arterial embolization of renal carcinomas, Cancer Res. $42: 3880-3883,1982$.

11) Hanna, N.: The role of natural killer cell in the control of tumor growth and metastasis. Biochimica et Biophysica Acta 780:213-226, 1985. 
12）佐藤一成, 守山正㹸, 阿部良说, 加藤哲郎, 加藤敏郎他：抗癌剂マイクロカプセル化学塞栓療法の酰床成 續. DDS 4 (1):15-19, 1989.

13）沼崎洋三, 岩野勝行, 菊地幹雄, 石田名香雄: Neocarzinostatin(NCS) のマクロファージ活性化作用. 医学 のあゆみ 123(11): 992-994, 1982.

14）岩本昭彦, 咲田雅一, 畑 幸樹, 荻原明於, 高橋俊雄・
他：活性炭吸着マイトマイシンによる腹空内マクロ ファージの活性化について. 日癌治誌 $22(8): 634$, 1987.

15）田中義憲, 紏川友秀, 青池 最: 胃癌患者に占ける Natural killer 活性の解析. I. 進行度との関連性と 術後の経過. 臨床免疫 $14: 227-236,1982$. 